引用格式:王静茹,马龙,刘廷急,等. 1951-2012年科尔沈沙地气温在突变前后的时空对比 [J]. 资源科学, 2016,38(4):690-703. [Wang J R, Ma L, Liu T X, et al. Comparative analysis of temperature before and after abrupt changes in Horqin Sandy Land from 1951 to 2012[J]. Resources Science, 2016,38(4):690-703]. DOI: 10.18402/resci.2016.04.11

\title{
1951-2012 年科尔沁沙地气温在突变前后的时空对比
}

\section{王静茹,马 龙,刘廷隹, 黄 星, 刘丹辉, 李虹雨}

(内蒙古农业大学水利与土木建筑工程学院, 呼和浩特 010018 )

\begin{abstract}
摘 要: 为促进科尔沁沙地生态环境保护、农牧业发展、水资源合理开发利用等的顺利开展, 本文利用 19512012 年科尔沁沙地气温资料,分析了该区气温突变特征及突变前后时空演变情况, 结果表明: (1)时间上, 年(季)最 低气温首先发生突变(1981-1987年), 平均气温次之(1981-1994年), 最高气温最晚(1985-1999年) ; 冬、春、秋、夏 季依次发生突变; (2)年最低气温突变后比突变前、冬季气温比夏季气温变化更剧烈; 年、春(秋)季气温变化剧烈程 度按最低、平均、最高气温依次减弱, 冬季与之相反; 3 突变前春季最低气温升温速率为 $0.50^{\circ} \mathrm{C} / 10 \mathrm{a}$ 、突变后秋季最 高气温升温速率为 $0.75^{\circ} \mathrm{C} / 10 \mathrm{a}$, 二者对升温贡献最大; (4) 突变前后多年均值增量最大为冬季最低气温 $\left(1.86^{\circ} \mathrm{C}\right)$, 气候 倾向率增量最大为秋季最高气温 $\left(0.72^{\circ} \mathrm{C} / 10 \mathrm{a}\right)$; 年内季节多年均值增量变化顺序与其增温速率增量变化相反; (5)空 间上, 年气温各要素突变后倾向率变化范围均较突变前增大, 年最低气温突变后显著升温面积比突变前增大 $6.79 \%$; 突变后, 除科左中旗地区平均气温外, 自东向西沿新开河到西辽河以北地区升温速率大于以南地区升温 速率。
\end{abstract}

关键词:科尔沁沙地; 气温; 突变; 时空变化;对比分析

DOI: $10.18402 /$ resci.2016.04.11

\section{1 引言}

2013 年根据 IPCC 第五次气候变化评估系列报 告指出: 北半球从1983-2012年可能是最近 1400 年 来气温最高的 30 年, 21 世纪第一个 10 年则是最温 暖的十年 ${ }^{[1,2]}$ 。全球部分陆地出现干旱化、沙漠化趋 势 ${ }^{[3,4]}$,气温、降水以及人类活动都是重要的影响因 素 ${ }^{[5-8]}$ 。

气温变化在世界各地不同时段表现出区域性 特征。20世纪 20 年代- 20 世纪 40 年代是全球变暖 周期,在北美、非洲、北极表现得非常显著,而欧洲、 澳洲和亚洲并不显著, 且在亚洲中、西部仍为降温 区; 但在 20 世纪 70 年代后的变暖周期内, 除澳洲反 映不明显外, 其它各大洲都有显著的升温 ${ }^{[9,10]}$, 而近 几十年来北半球中纬度地区升温最快 ${ }^{[1]}$ 。中国从
20 世纪 60 年代左右到 21 世纪初, 对于全球变暖的 响应北方各地区更为显著 ${ }^{[12-17]}$, 且高于全国平均增 幅 ${ }^{[17]}$, 其中东北地区升温趋势最快 ${ }^{[18,19]}$, 最低温度的 升温速率大于最高温度的升温速率, 冬季温度的升 温速率大于夏季升温速率 ${ }^{[20,21]}$ 。 20 世纪 80 年代以 前, $100^{\circ} \mathrm{E}$ 以东和 $35^{\circ} \mathrm{N}$ 以南地区以四川盆地为中心 的变冷区, 从 80 年代末期才开始变暖 ${ }^{[22]}$ 。而在中国 东部季风区增温速率自南向北呈降低趋势[123]。对于 全球的快速增温,许多研究者亦揭示出气温存在突 变的一些事实,且突变年份具有区域性特征 ${ }^{[23-27]}$ 。 中国东部季风区年平均气温在 1987 年发生突变 ${ }^{[23]}$, 陕南地区在1994 年发生突变 ${ }^{[24]}$, 而青藏高原年平均 气温在 1995 年发生突变, 甘肃和新疆南部地区大多 发生在 1995年之前 125$]$ 。总体来看中国北部区域气温

收稿日期: 2015-08-18 ; 修订日期: 2016-01-06

基金项目: 国家自然科学基金资助项目(50869005); 内蒙古自治区自然科学基金资助项目(2014MS0407)。

作者简介: 王静茹, 女, 内蒙古呼和浩特人, 硕士生, 主要从事水文及水资源, 环境演变、气候变化及二者响应关系研究。 E-mail: 339199034@qq.com

通讯作者:马龙,E-mail : malong4444333@163.com 
突变的时间早于南部,亦有部分区域没有明显的突 变发生 ${ }^{[26]}$ 。对于科尔沁沙地,已有相关研究表明,在 近 25 年 (1981-2005 年) ${ }^{[28]} 、 45$ 年左右 (1961-2005 年 左右 $)^{[19,29]}$ 、55 年左右 $(1951-2006 \text { 年左右 })^{[30,31]}$ 的时间 尺度内, 气温升高幅度大、速度快, 与中国北方地区 总体温度变化趋势一致,且在 1987 年年平均气温发 生了突变 ${ }^{[27]}$ 。

以上研究大部分从年、年代、季的时间尺度揭 示了气温升降、周期、突变等基本特征,其中突变是 一个明显的气候状态分界点, 可作为气候变化的自 然时间分界点,较少有学者以此为界对突变前后的 气候状态做进一步分析。科尔沁沙地在历史上曾 为水草丰美、植被茂盛的大草原, 属典型的北温带 半干旱风沙区,也是中国北方半干旱农牧交错区生 态脆弱带 ${ }^{[32,33]}$, 经过近百年的草场退化、沙化及土地 荒漠化,已成为中国四大沙地之一。其地表环境的 变化不论在全球还是中国都具有典型性和代表性, 对其变化驱动力之一的气温变化特征的分析即显 得十分必要。基于此,本文以覆盖科尔沁沙地及周 边地区的 27 个气象站点 1951-2012 年气象数据为 基础,对科尔沈沙地的最高气温、平均气温、最低气 温的年、季节变化做突变分析,并以突变点为时间 分界点, 对各气温要素突变前后的基本特征作对比
分析。

\section{2 研究区概况与研究方法}

\section{1 研究区概况}

科尔沁沙地范围见图 1 , 其地理位置界于 $117^{\circ}$ $45^{\prime} \mathrm{E}-124^{\circ} 06^{\prime} \mathrm{E}, 42^{\circ} 36^{\prime} \mathrm{N}-45^{\circ} 20^{\prime} \mathrm{N}$ 之间, 属辽河中游 冲积平原,现状地貌形态主要包括固定沙地、半固 定沙地和流动沙丘。风沙土是科尔沁沙地面积最 大的土类,其次是草甸土、栗钙土、盐碱土、暗棕壤 土、黑钙土等。植被区系处于内蒙古、长白和华北 植物区系的交汇地,植物种类较为丰富。该地区年 降水量在 200 650 mm 之间, 70\% 的降水集中在 6月、 7 月、8 月 3 个月份; 年蒸发量在 $1600 \sim 2400 \mathrm{~mm}$ (蒸 发血为 $\varphi 20 \mathrm{~cm}$ 口径)之间,主要集中在 4-9月,此间 蒸发量占全年蒸发量的 $78 \%$ 左右; 夏季炎热,冬季 漫长干冷, 多年平均气温在 $6^{\circ} \mathrm{C}$ 左右 ${ }^{[34]}$

\section{2 数据来源}

本次共收集了科尔沁沙地及其周边地区分布 的 27 个气象站点。这些站点自建站以来至 2012 年 的最高气温、平均气温、最低气温的逐月数据集 ${ }^{[35}$ (个别数据缺测, 进行了插补)。经检验, 各气象站 点各类气象因子数据无明显的突变点和随机变化, 数据变化相对均一和一致, 数据可靠, 可以代表区 域气候状况。

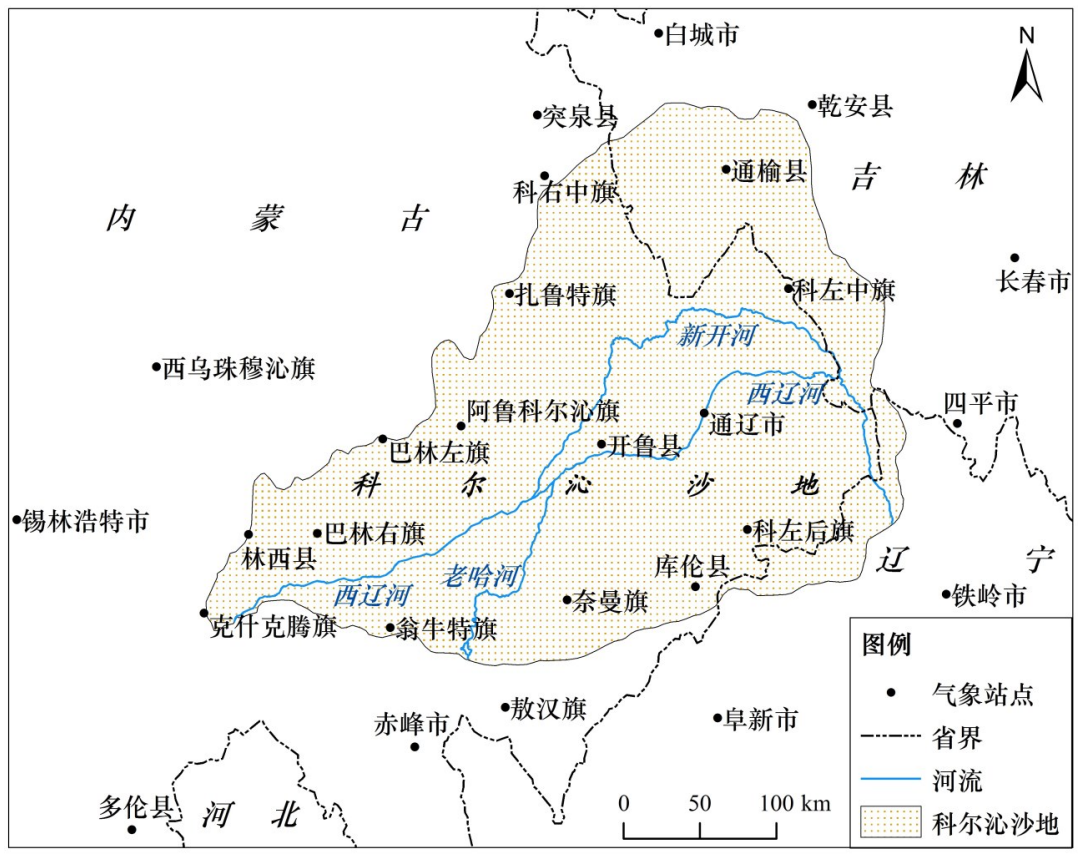

图 1 科尔沁沙地位置及气象站点分布

Figure 1 The position of Horqin Sandy Land and distribution of meteorological station 


\section{3 数据处理及研究方法}

(1) 对于缺测数据的插补延展, 采用相关分析 及回归分析法。

(2)对于科尔沁沙地区域平均气象数据序列采 用客观运行法进行求取,即将区域分成网格,形成 格点, 用研究区内外各气象站的气象资料,采用邻 近各站权重 (取距离因子)及综合权重确定各格点 气候数据, 取各格点数据的算术平均值, 即为整个 区域平均值序列。

(3)对于气温突变检验采用 Mann-Kendall 非参 数统计法 (由 Matlab 7.1 编程实现), 其中 UF 和 UB 为标准正太分布, 当 $U F$ 与 $U B$ 两条线的交点位于信 度线之内, 且只有一个交点, 此交点即为突变年份, 当两条线的交点位于信度线之外，或同时检验出多 次突变点时,综合考虑实测值和 5 年滑动平均值进 一步确定突变点。

(4)对于数据序列的趋势分析,采用最小二乘 法,并用 $\mathrm{F}$ 检验对趋势变化的显著与否进行检验。

(5)对于气温要素变化的剧烈程度,使用变异 系数 $C v$ 表示, $C v=|S D / M N|$ ( $S D$ 为标准差, $M N$ 为平 均值); $C v$ 值越大, 表明气温变化越剧烈。

(6) 使用 5 年滑动平均值法进一步分析气温各 要素的周期及趋势变化。

(7) 对于气温的空间分布变化的分析, 采用 ArcGIS 10.0 软件, 将各站点气温的气候倾向率, 使 用克里金插值法以 $250 \mathrm{~m} \times 250 \mathrm{~m}$ 的空间分辨率分布 于整个研究区,并用 $\mathrm{F}$ 检验对气温空间变化显著与 否所占的面积做检验。

\section{3 结果与分析}

\section{1 气温的突变检验}

气候突变 (包括气温突变) 是指从一种稳定态 (或稳定持续的变化趋势) 跳跃式地转变到另一种 稳定态(或稳定持续地变化趋势)的现象,它表现为 气候在时空上从一个统计特性到另一个统计特性 的急剧变化 ${ }^{[36]}$ 。1951-2012 年科尔沈沙地区域平均 年(季)各气温要素 Mann-Kendall突变检验见图 2。

(1)年、春季、夏季、秋季、冬季最高气温发生突 变的年份分别为 1992年、1991 年、1999年、1994年、 1985 年, 开始持续升温 (UF 曲线始终大于 0 ) 的趋势 分别从 1989年、1982年、2000年、1994年、1987年开
始, 显著升温 (超过置信度 $\alpha=0.05$ 显著性检验)分别 从 2003 年、 2001 年、 2009 年、 2008 年和 2011 年(只 有两年显著)、1997年(其中 2001 年又不显著)开 始; 冬季突变最早,夏季最晚,二者相隔 15 年。

(2)年、春季、夏季、秋季、冬季平均气温发生突 变的年份分别为 1987 年、1986年、1994年、1987年、 1981 年,其中年平均气温发生突变的时间与中国东 部季风区突变年份一致(1961-2006年) ${ }^{[23]}$,开始持 续升温的趋势分别从 1959 年、1971 年、1971 年、 1969 年、1975 年开始,其中年平均气温保持持续升 温趋势的时间与东北地区时间基本一致,显著升温 分别从1997年、1996年、2004年、1993年、1995年开 始; 亦是冬季突变最早,夏季最晚,二者相隔 14 年。

(3)年、春季、夏季、秋季、冬季最低气温发生突 变的年份分别为 1981 年、1981 年、1987年、1982 年、 1981 年,开始持续升温的趋势分别从 1951 年、1958 年、1951年、1953年、1978 年开始,显著升温分别从 1992 年、1990年、1996年、1988年、1993 年开始; 春、 冬季突变最早,夏季最晚,二者相隔 7 年。

由此可知,年、春季、冬季最低气温突变时间最 早 (1981 年), 夏季最高气温突变时间最晚 (1999 年)。除最低气温的春、冬季突变年份相同外(1981 年), 各气温要素年内季节突变早晚顺序依次为冬 季、春季、秋季、夏季, 与中国四季平均气温突变早 晚顺序一致(1951-2003 年) ${ }^{[26]}$, 除冬季平均气温和 最低气温突变年份相同外(1981 年),年、各季节的 突变年份均表现为最低气温早于平均气温,平均气 温又早于最高气温,且三者的突变年份间隔4 7年。

\section{2 气温突变前后的年、季节变化}

区域平均的年(季)各气温要素突变前后的基 本特征变化见图 3 。气温突变年变化方面,年最高 气温多年均值突变后比突变前升高 $0.83^{\circ} \mathrm{C}$, 突变前 极值差为 $3.24^{\circ} \mathrm{C}$, 突变后极值差为 $3.05^{\circ} \mathrm{C}$ 。突变前 后变异系数分别为 $0.06 、 0.05$ 。突变前有较明显的 周期波动缓慢上升,共出现 4 次峰值, 4 次谷值 (以 较大而明显的周期为准 ), 气候倾向率为 $0.07^{\circ} \mathrm{C} /$ $10 \mathrm{a}$, 但不显著; 突变后周期波动相对减弱, 只有 2 次 明显的谷值，且显著上升(通过了显著性水平 $\alpha=5 \%$ 的 $\mathrm{F}$ 检验), 气候北向率为 $0.26^{\circ} \mathrm{C} / 10 \mathrm{a}$; 突变前后气候 倾向率的增量为 $0.19^{\circ} \mathrm{C} / 10 \mathrm{a}$ 。 


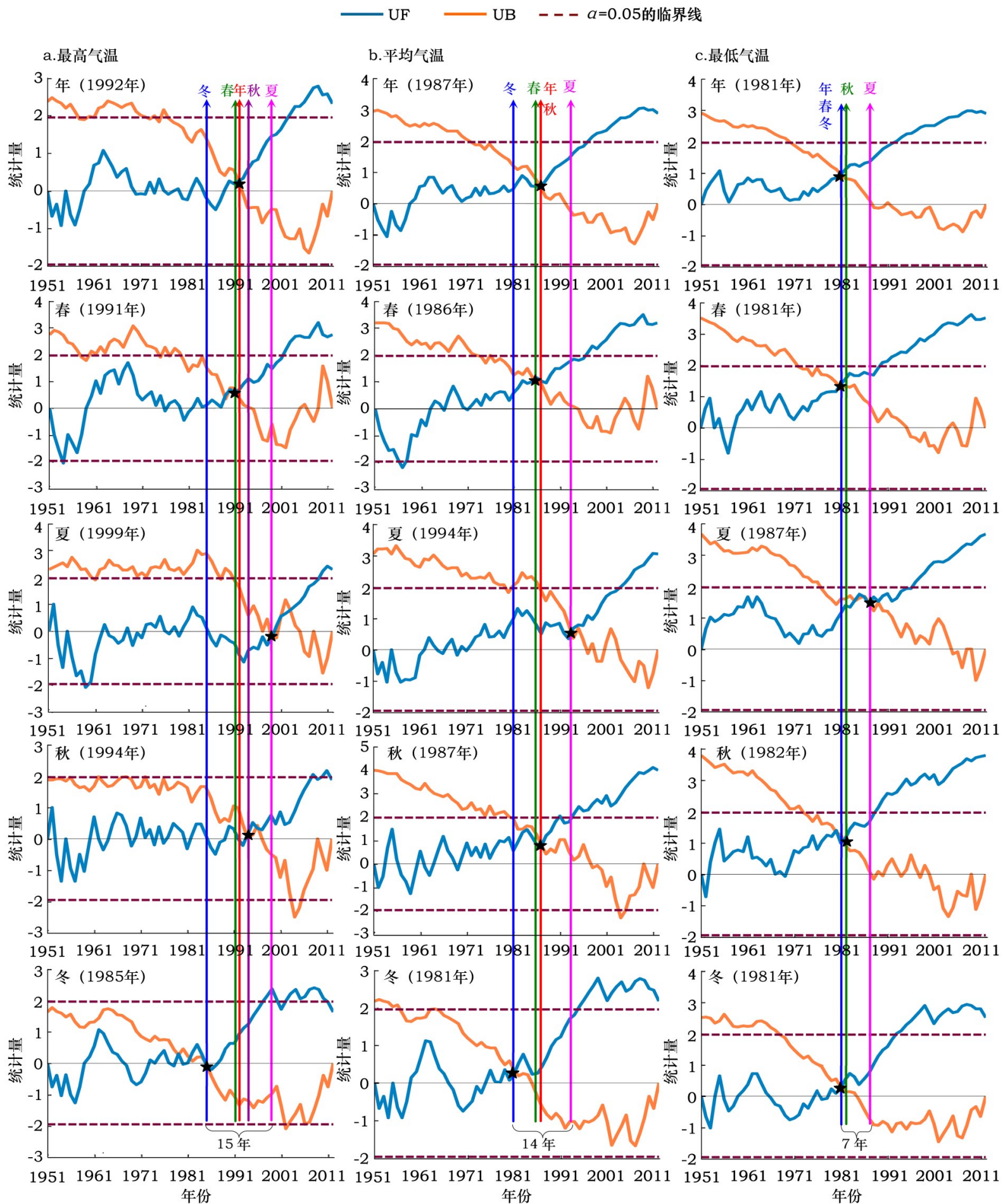

注:贯穿图中的坚线为年和各季节突变年份的示意线; $\star$ 为突变年份示意点。

图 2 1951-2012 年科尔沁沙地区域平均的年 (季)各气温要素的 Mann-Kendall 突变检验

Figure 2 The regional average of year(season) all temperature elements abrupt in Horqin Sandy Land from 1951 to 2012

年平均气温多年均值突变后比突变前升高 $1.19^{\circ} \mathrm{C}$ 。突变前极值差为 $2.85^{\circ} \mathrm{C}$, 突变后极值差为 $2.51^{\circ} \mathrm{C}$ 。突变前后变异系数分别为 $0.11 、 0.10$ 。突变
前有较明显的周期波动缓慢上升,共出现 3 次峰值, 3 次谷值,气候倾向率为 $0.19^{\circ} \mathrm{C} / 10 \mathrm{a}$; 突变后周期波 动相对减弱, 只有 3 次较明显的谷值, 气候倾向率为 


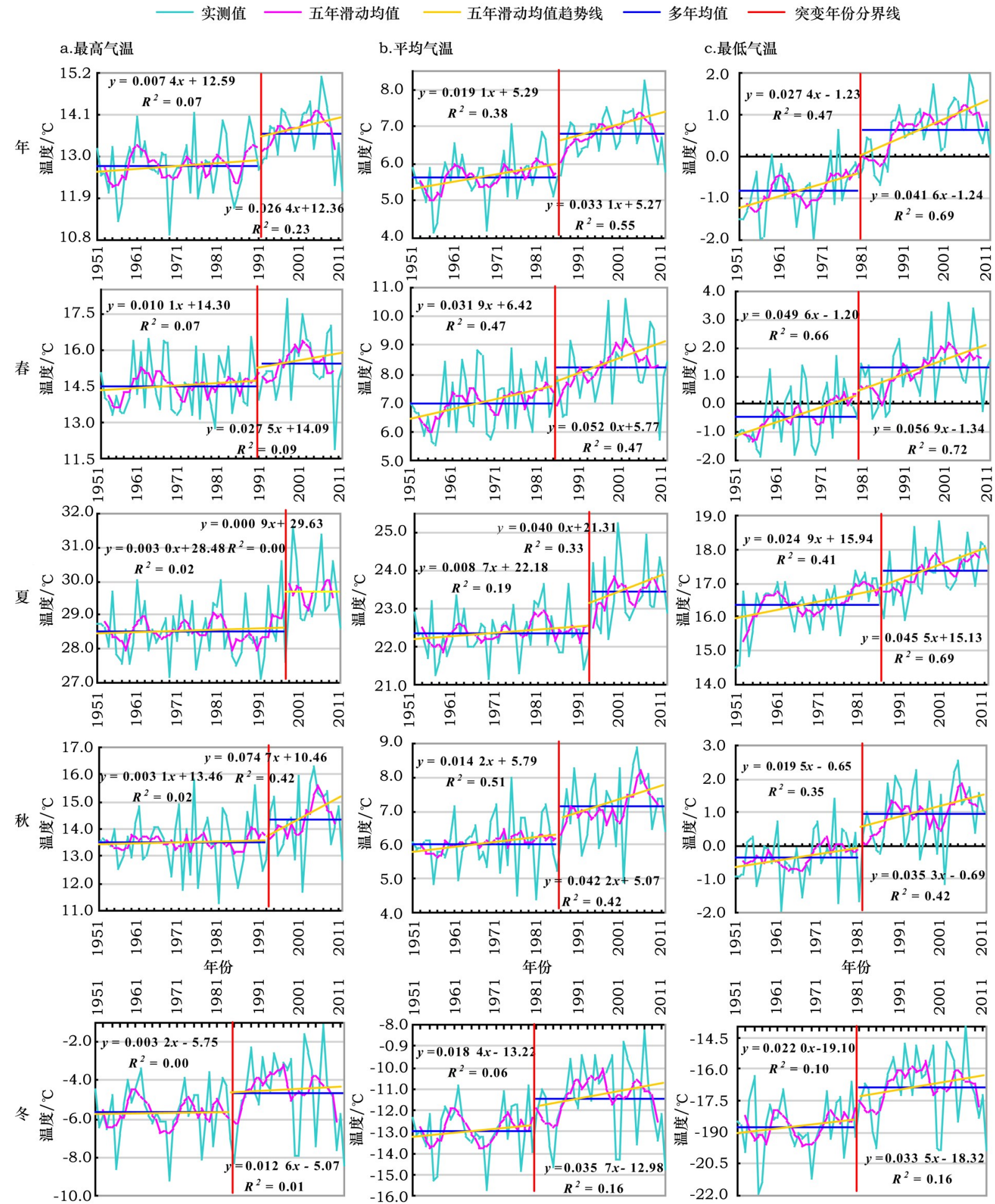

图 3 科尔沁沙地区域平均的年 (季)各气温要素值、多年均值、五年滑动平均值突变前后对比

Figure3 The regional average of year (season)temperature elements' value, mean value for many years, five years moving average of compare the change of the abrupt temperature change before and after in Horqin Sandy Land

$0.33^{\circ} \mathrm{C} / 10 \mathrm{a}$; 气温突变前后均呈显著上升趋势, 气候 倾向率增量为 $0.14^{\circ} \mathrm{C} / 10 \mathrm{a}$ 。

年最低气温多年均值突变后比突变前升高 $1.47^{\circ} \mathrm{C}$ 。突变前极值差为 $2.63^{\circ} \mathrm{C}$, 突变后极值差为 $2.63^{\circ} \mathrm{C}$ 。突变前后变异系数分别为 $0.76 、 0.98$ 。突变 前出现 2 次峰值, 2 次谷值, 气候倾向率为 $0.27^{\circ} \mathrm{C} /$ 
$10 \mathrm{a}$; 突变后变化相对剧烈, 出现 2 次峰值, 3 次谷值, 气候倾向率为 $0.42^{\circ} \mathrm{C} / 10 \mathrm{a}$; 突变前后均呈显著上升 趋势, 气候倾向率增量为 $0.14^{\circ} \mathrm{C} / 10 \mathrm{a}$ 。

综上所述, 年最高气温和年平均气温突变前极 值差相对较大, 年最低气温突变前后极值差一致。 年最高气温和年平均气温突变前后变化剧烈程度 基本一致,突变前后变异系数差为 0.01 ,而年最低 气温突变后变化更剧烈, 突变前后变异系数差为 0.18 。年最高气温、年平均气温、年最低气温三者突 变前后多年均值升温幅度依次增大。三者突变前 后的升温速率(气候倾向率)增量为年最高气温最 大, 年最低气温次之, 年平均气温最小。

限于篇幅,此处不再展开叙述四季各气温要素 突变前后的变化,现将其基本特征值列于表 1 、表 2 、 表3。
综合图 3 及表 1 、表 2 、表 3 可知,除夏季最高气 温突变后的极值差小于突变前外,其它季节各气温 要素均为突变后大于突变前; 各气温要素突变前后 均表现为冬季极值差大于夏季极值差; 春季、夏季、 冬季各气温要素突变前极值差以最高气温、最低气 温、平均气温的顺序依次减小,秋季则以最高气温、 平均气温、最低气温的顺序依次减小; 各季节突变 后极值差均以最高气温、平均气温、最低气温的顺 序依次减小。从变异系数来看,冬季各气温要素突 变后较突变前变化更剧烈,春、秋季最低气温突变 前较突变后变化更剧烈,其它季节各气温要素突变 前后变化剧烈程度基本一致;各气温要素突变前后 均表现为冬季气温较夏季气温变化剧烈; 春季、秋 季各气温要素突变前后均表现为最低气温变化的 剧烈程度大于平均气温, 平均气温大于最高气温,

\section{表 1 科尔沁沙地区域平均的各季节最高气温突变前后的基本特征}

Table 1 The fundamental of regional average of each season maximum temperature before and after abrupt temperature change in Horqin Sandy Land

\begin{tabular}{|c|c|c|c|c|c|c|c|c|}
\hline & & $\begin{array}{c}\text { 多年均值 } \\
{ }^{\circ} \mathrm{C}\end{array}$ & $\begin{array}{c}\text { 极大值 } \\
/{ }^{\circ} \mathrm{C} \text { (年份) }\end{array}$ & $\begin{array}{c}\text { 极小值 } \\
\text { / }{ }^{\circ} \mathrm{C} \text { (年份) }\end{array}$ & $\begin{array}{c}\text { 极值差 } \\
{ }^{\circ} \mathrm{C}\end{array}$ & 变异系数 & $\begin{array}{c}\text { 气候倾向率 } \\
/\left({ }^{\circ} \mathrm{C} / 10 \mathrm{a}\right)\end{array}$ & $\begin{array}{l}\text { 峰(谷) } \\
\text { 值 (次) }\end{array}$ \\
\hline \multirow[t]{2}{*}{ 春季 } & 突变前 & 14.51 & $16.55(1989)$ & $12.75(1980)$ & 3.80 & 0.08 & 0.101 & $3(4)$ \\
\hline & 突变后 & 15.43 & $18.13(1998)$ & $11.92(2010)$ & 6.21 & 0.09 & 0.275 & $1(0)$ \\
\hline \multirow[t]{2}{*}{ 夏季 } & 突变前 & 28.54 & $30.59(1997)$ & $27.11(1992)$ & 3.39 & 0.03 & 0.030 & $4(5)$ \\
\hline & 突变后 & 29.70 & $31.58(2000)$ & $28.55(2012)$ & 3.03 & 0.03 & 0.009 & $1(1)$ \\
\hline \multirow[t]{2}{*}{ 秋季 } & 突变前 & 13.50 & $15.80(1975)$ & $11.28(1981)$ & 4.52 & 0.07 & 0.031 & $0(0)$ \\
\hline & 突变后 & 14.35 & $16.28(2005)$ & $11.72(2002)$ & 4.56 & 0.09 & $0.747 *$ & $1(1)$ \\
\hline \multirow[t]{2}{*}{ 冬季 } & 突变前 & -5.65 & $-3.38(1962)$ & $-9.23(1969)$ & 5.85 & 0.24 & 0.032 & $3(3)$ \\
\hline & 突变后 & -4.69 & $-1.09(2007)$ & $-8.51(2012)$ & 7.43 & 0.45 & 0.126 & $2(1)$ \\
\hline
\end{tabular}

注: *表示通过显著性水平 $(\alpha=0.05) \mathrm{F}$ 检验。

表 2 科尔沁沙地区域平均的各季节平均气温突变前后的基本特征

Table 2 The fundamental of regional average of each season mean temperature before and after abrupt temperature change in Horqin Sandy Land

\begin{tabular}{|c|c|c|c|c|c|c|c|c|}
\hline & & $\begin{array}{c}\text { 多年均值 } \\
{ }^{\circ} \mathrm{C}\end{array}$ & $\begin{array}{c}\text { 极大值 } \\
\text { / }{ }^{\circ} \mathrm{C} \text { (年份) }\end{array}$ & $\begin{array}{c}\text { 极小值 } \\
\text { / } \mathrm{C} \text { (年份) }\end{array}$ & $\begin{array}{c}\text { 极值差 } \\
{ }^{\circ} \mathrm{C}\end{array}$ & 变异系数 & $\begin{array}{c}\text { 气候倾向率 } \\
/\left({ }^{\circ} \mathrm{C} / 10 \mathrm{a}\right)\end{array}$ & $\begin{array}{l}\text { 峰(谷) } \\
\text { 值 (次) }\end{array}$ \\
\hline \multirow[t]{2}{*}{ 春季 } & 突变前 & 7.00 & $8.91(1975)$ & $5.50(1957)$ & 3.41 & 0.15 & $0.319 *$ & $4(4)$ \\
\hline & 突变后 & 8.25 & $10.61(2002)$ & $5.70(2010)$ & 4.91 & 0.14 & $0.520 *$ & $2(2)$ \\
\hline \multirow[t]{2}{*}{ 夏季 } & 突变前 & 22.36 & $23.66(1988)$ & $21.17(1969)$ & 2.49 & 0.03 & $0.087 *$ & $4(5)$ \\
\hline & 突变后 & 23.45 & $25.24(2000)$ & $22.22(2012)$ & 3.02 & 0.04 & $0.400 *$ & $2(1)$ \\
\hline \multirow[t]{2}{*}{ 秋季 } & 突变前 & 6.04 & $8.01(1975)$ & $4.37(1981)$ & 3.64 & 0.13 & $0.142 *$ & $0(0)$ \\
\hline & 突变后 & 7.13 & $8.91(2005)$ & $4.93(2002)$ & 3.98 & 0.14 & $0.422 *$ & $2(2)$ \\
\hline \multirow[t]{2}{*}{ 冬季 } & 突变前 & -12.93 & $-10.81(1962)$ & $-15.70(1969)$ & 4.89 & 0.09 & 0.184 & $2(3)$ \\
\hline & 突变后 & -11.47 & $-8.24(2007)$ & $-14.82(2012)$ & 6.58 & 0.15 & $0.357 *$ & $2(2)$ \\
\hline
\end{tabular}


表 3 科尔沁沙地区域平均的各季节最低气温突变前后的基本特征

Table 3 The fundamental of regional average of each season minimum temperature before and after abrupt temperature change in Horqin Sandy Land

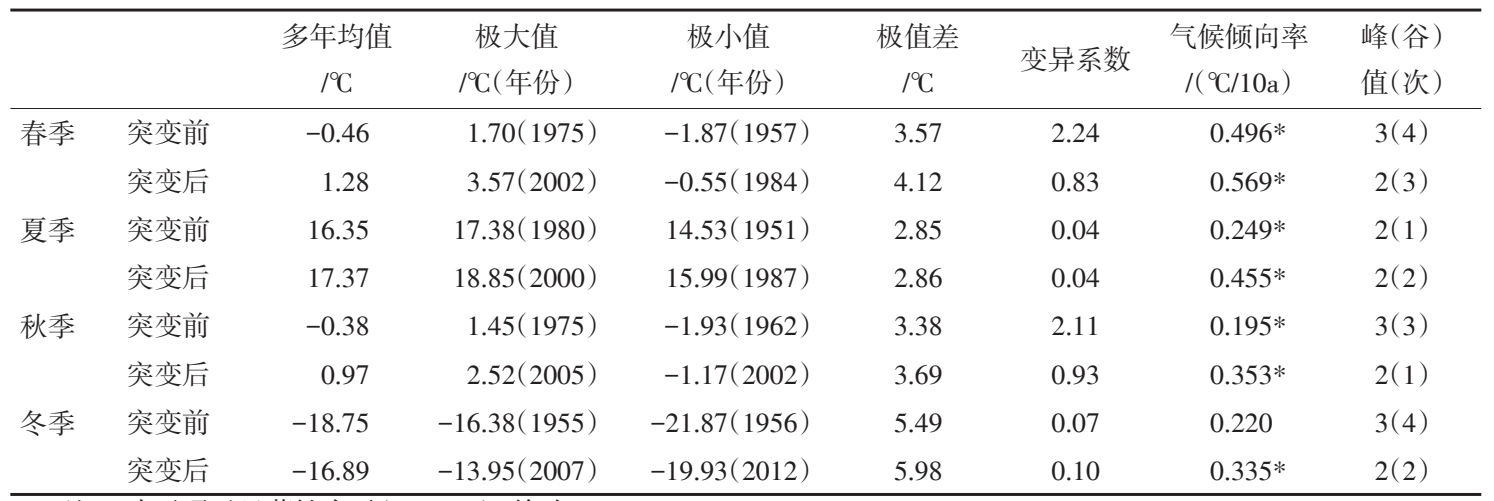

注: *表示通过显著性水平 $(\alpha=0.05) \mathrm{F}$ 检验。

冬季各气温要素与之呈相反的顺序, 夏季各气温要 素变化剧烈程度基本一致。

最高气温突变之前春季气候倾向率最大, 为 $0.10^{\circ} \mathrm{C} / 10 \mathrm{a}$, 突变之后秋季气候倾向率最大, 为 $0.75^{\circ} \mathrm{C} / 10 \mathrm{a}$ ，二者对最高气温升温的贡献最大。平均 气温突变前后均为春季气候倾向率最大, 分别为 $0.32^{\circ} \mathrm{C} / 10 \mathrm{a}$ 和 $0.52^{\circ} \mathrm{C} / 10 \mathrm{a}$, 对平均气温升温的贡献最 大。最低气温突变前后亦均为春季气候倾向率最 大, 分别为 $0.50^{\circ} \mathrm{C} / 10 \mathrm{a}$ 和 $0.57^{\circ} \mathrm{C} / 10 \mathrm{a}$, 对最低升温的 贡献最大。最高气温只有秋季突变后升温趋势较 为显著, 平均气温和最低气温均只有冬季突变前升 温趋势不显著。春季、夏季突变前后、秋季、冬季突 变前均为最低气温升高对升温的贡献最大, 平均气 温次之,最高气温最小; 秋季气温突变后与之呈相 反的趋势; 冬季气温突变后, 平均气温的贡献最大, 最高气温最小。总体来看, 春季气温、最低气温升 高对升温的贡献最大。另外,整体上各季节突变前 的周期波动较突变后明显。

四季最高气温多年均值突变前后增量大小顺 序为夏季 $\left(1.16^{\circ} \mathrm{C}\right)$ 、冬季 $\left(0.96^{\circ} \mathrm{C}\right)$ 、春季 $\left(0.92^{\circ} \mathrm{C}\right)$ 、秋 季 $\left(0.85^{\circ} \mathrm{C}\right)$; 气候倾向率突变前后增量大小顺序为 秋季 $\left(0.72^{\circ} \mathrm{C} / 10 \mathrm{a}\right)$ 、春季 $\left(0.17^{\circ} \mathrm{C} / 10 \mathrm{a}\right)$ 、冬季 $\left(0.09^{\circ} \mathrm{C} /\right.$ $10 \mathrm{a})$ 、夏季 $\left(-0.02^{\circ} \mathrm{C} / 10 \mathrm{a}\right)$, 各季节突变前后多年均值 增量大的速率(气候倾向率)增量反而小。平均气 温多年均值突变前后增量大小顺序为冬 $\left(1.46^{\circ} \mathrm{C}\right)$ 、 春季 $\left(1.25^{\circ} \mathrm{C}\right)$ 、夏季 $\left(1.09^{\circ} \mathrm{C}\right)$ 、秋季 $\left(1.09^{\circ} \mathrm{C}\right)$, 气候倾 向率突变前后增量大小顺序为夏季 $\left(0.31^{\circ} \mathrm{C} / 10 \mathrm{a}\right)$ 、秋 季 $\left(0.28^{\circ} \mathrm{C} / 10 \mathrm{a}\right)$ 、春季 $\left(0.20^{\circ} \mathrm{C} / 10 \mathrm{a}\right)$ 、冬季 $\left(0.17^{\circ} \mathrm{C} /\right.$ 10a), 变化规律与最高气温一致。最低气温多年均 值突变前后增量大小顺序为冬季 $\left(1.86^{\circ} \mathrm{C}\right)$ 、春季 $\left(1.74^{\circ} \mathrm{C}\right) 、$ 秋季 $\left(1.35^{\circ} \mathrm{C}\right)$ 、夏季 $\left(1.02^{\circ} \mathrm{C}\right)$, 气候倾向率 突变前后增量大小顺序为夏季 $\left(0.21^{\circ} \mathrm{C} / 10 \mathrm{a}\right)$ 、秋季 $\left(0.16^{\circ} \mathrm{C} / 10 \mathrm{a}\right)$ 、冬季 $\left(0.12^{\circ} \mathrm{C} / 10 \mathrm{a}\right)$ 、春季 $\left(0.07^{\circ} \mathrm{C} / 10 \mathrm{a}\right)$, 变化规律亦与最高气温基本一致。由此可知, 春 季、秋季、冬各气温要素突变前后多年均值增量以 最高气温、平均气温、最低气温的顺序依次增大,夏 季呈现与之相反的变化规律。夏季、冬季气候倾向 率增量均以平均气温最大, 最低气温次之, 最高气 温最小; 春季以平均气温最大, 最高气温次之, 最低 气温最小; 秋季以最高气温最大, 平均气温次之, 最 低气温最小。

\section{3 年气温突变前后的空间变化}

科尔沈沙地各气温要素年值突变前后倾向率 的空间分布见图 4。年最高气温在突变前后变化均 不显著 ( $\mathrm{F}$ 检验图略), 突变前 (图 4a) 整体以较微弱 的趋势升高, 西部升温趋势最大, 奈曼旗及周边地 区甚至有微弱的降低趋势,整体表现为沿老哈河和 新开河以北地区倾向率大于以南地区倾向率(科左 中旗地区除外)。突变后(如图 4b)变化趋势有所增 加,但仍不显著, 且降低趋势的变化幅度相对更大, 整体表现为自东向西沿新开河到西辽河的以北地 区倾向率大于以南地区倾向率, 同时呈自东向西逐 渐增大趋势, 且由负趋势逐渐变为正趋势。突变后 气候倾向率值变化范围较突变前有所增大。

年平均气温突变前 (图 4c) 整个科尔沈沙地呈 升温趋势, 其中在科右中旗和扎鲁特旗周边地区的 
a. 年最高气温突变前气候倾向率 $/\left({ }^{\circ} \mathrm{C} / 10 \mathrm{a}\right)$

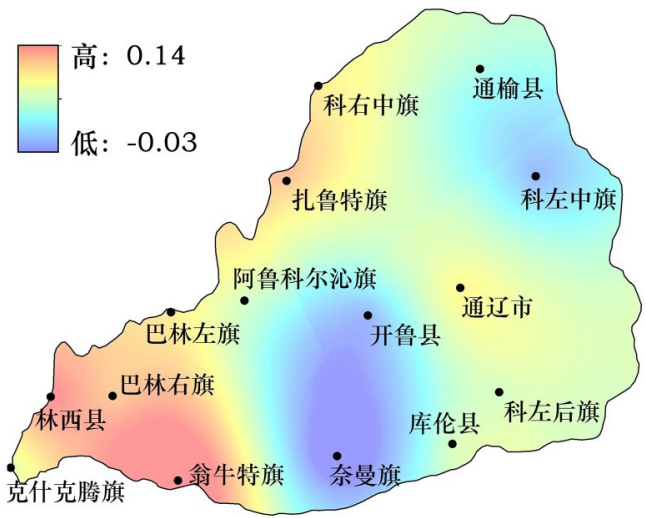

c. 年平均气温突变前气候倾向率 $/\left({ }^{\circ} \mathrm{C} / 10 \mathrm{a}\right)$

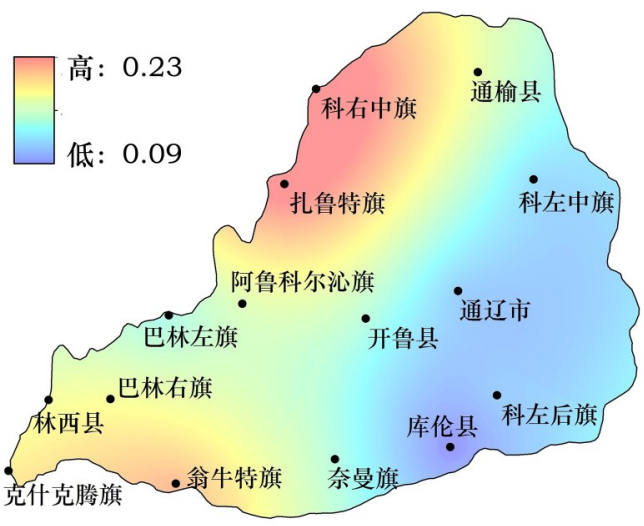

e. 年最低气温突变前气候倾向率/ $\left({ }^{\circ} \mathrm{C} / 10 \mathrm{a}\right)$

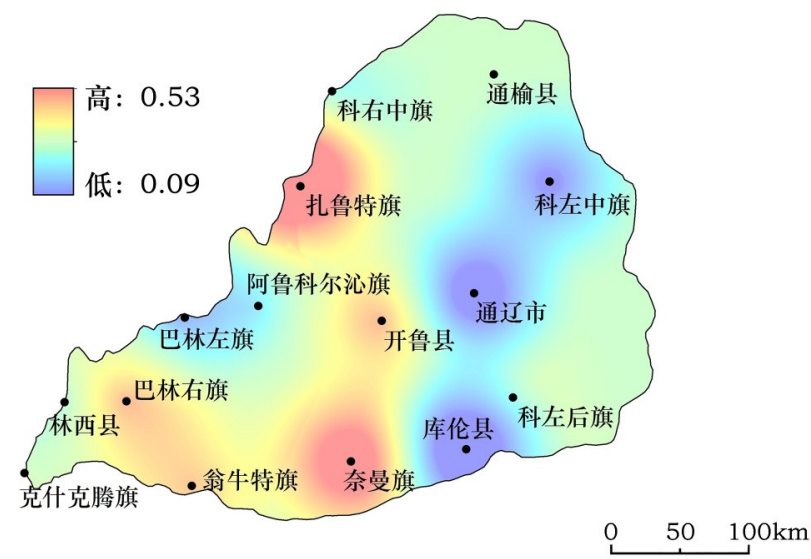

b.年最高气温突变后气候倾向率/ $\left({ }^{\circ} \mathrm{C} / 10 \mathrm{a}\right)$

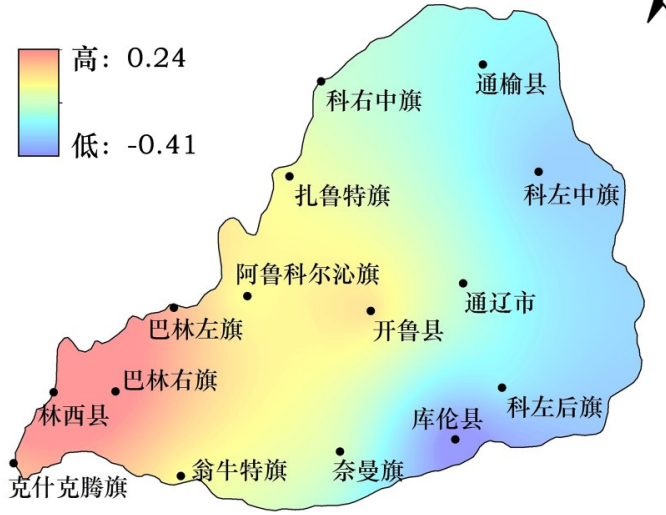

d.年平均气温突变后气候倾向率/ $\left({ }^{\circ} \mathrm{C} / 10 \mathrm{a}\right)$

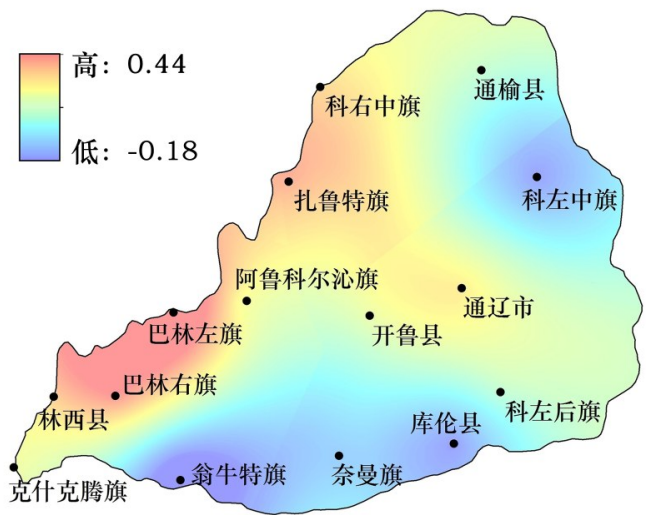

f. 年最低气温突变后气候倾向率/ $\left({ }^{\circ} \mathrm{C} / 10 \mathrm{a}\right)$

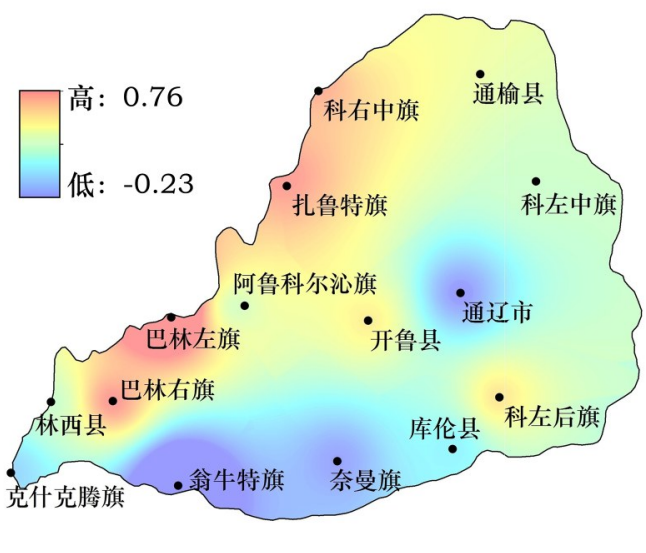

图 4 科尔沁沙地各气温要素突变前后气候倾向率空间分布

Figure 4 The spatial distribution of all temperature elements' climate tendency rate before and after abrupt temperature change in Horqin Sandy Land

气候倾向率最大, 且变化显著的 (通过显著性水平 $(\alpha=0.05) \mathrm{F}$ 检验, 见图 $5 \mathrm{a}$ 及表 4) 面积占整个研究区 的 $3.15 \%$; 科尔沁沙地东南部气候倾向率较小, 96.85\%的面积都呈不显著的升温趋势,整体表现为
沿老哈河和新开河以北地区倾向率大于以南地区 倾向率。突变后 (图4d)大部地区仍然呈升温趋势, 显著升高的面积占 $1.52 \%$ (见图 $5 \mathrm{~b}$ 及表 4 ); 巴林左 旗地区呈极显著升高(通过显著性水平 $(\alpha=0.01) \mathrm{F}$ 
a.年平均气温突变前

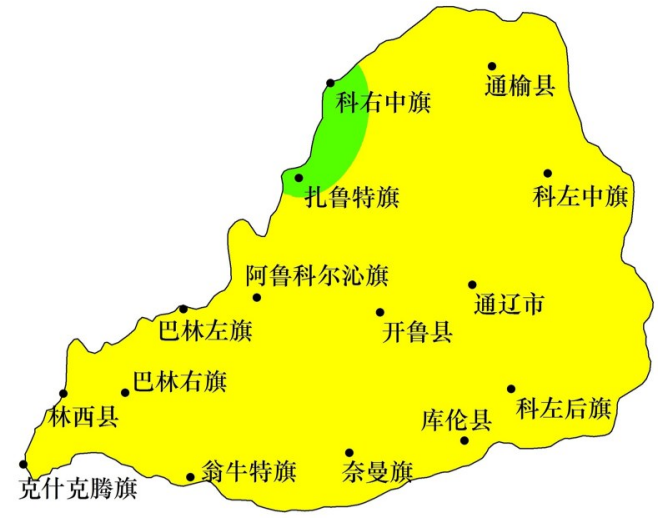

c.年最低气温突变前

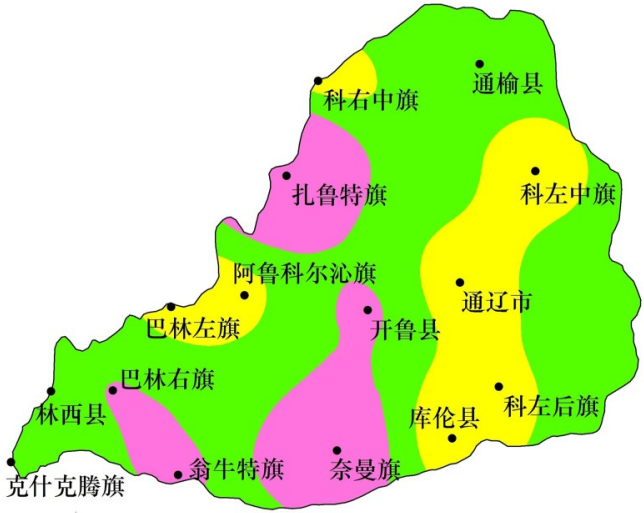

b. 年平均气温突变后

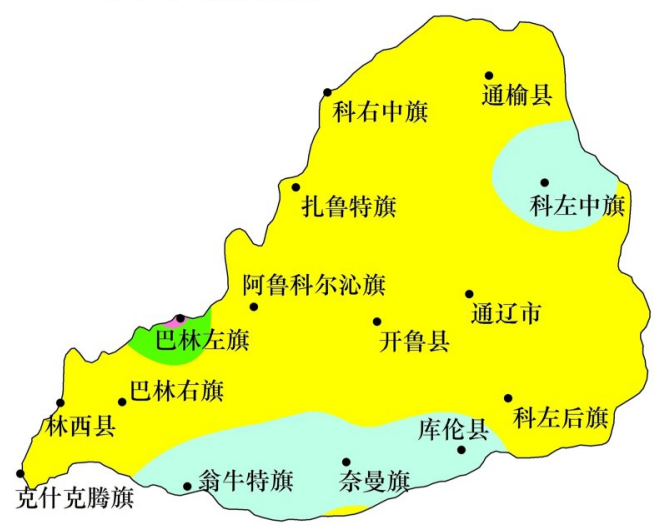

d.年最低气温突变后

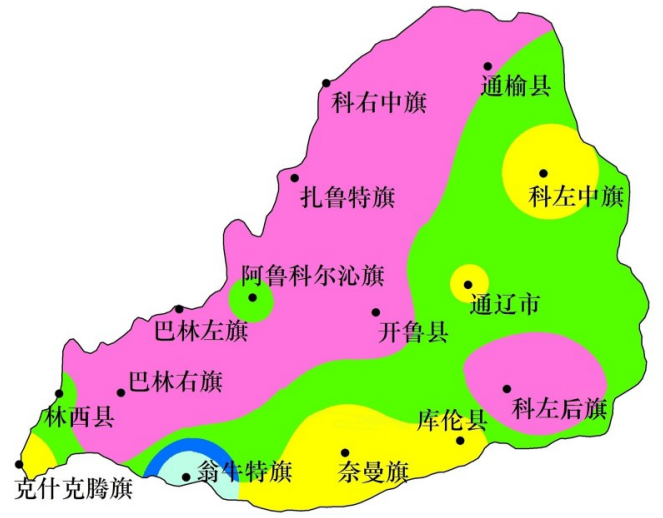
显著升高
极显著升高
图 例
不显著降低
显著降低
不显著升高
篮者的高

注: 显著升高(降低)表示通过显著性水平 $(\alpha=0.05) \mathrm{F}$ 检验,极显著升高(降低)表示通过显著性水平 $(\alpha=0.01) \mathrm{F}$ 检验。

图 5 科尔沁沙地年平均气温、最低气温变化显著性 $\mathbf{F}$ 检验空间分布

Figure 5 The spatial distribution of annual average temperature, minimum temperature change significance' F test before and after abrupt temperature change in Horqin Sandy Land

表 4 年平均气温、最低气温空间变化显著与否所占的面积比

Table 4 Occupied area ratio of annual average temperature, minimum temperature space variation significant or not

\begin{tabular}{lcccccc}
\hline 显著性 & & 不显著降低 & 显著降低 & 不显著升高 & 显著升高 & 极显著升高 \\
\hline 年平均气温 & 突变前 & - & - & 96.85 & 3.15 & - \\
& 突变后 & 19.22 & - & 79.14 & 1.52 & 0.11 \\
年最低气温 & 突变前 & - & - & 22.70 & 58.10 & 19.20 \\
& 突变后 & 1.17 & 0.81 & 13.92 & 35.67 & 48.42 \\
\hline
\end{tabular}

检验); 在翁牛特旗、奈曼旗、库伦县、科左中旗等地 周围年平均气温有所降低,但不显著,整体表现为 自东向西沿新开河到西辽河的以北地区倾向率大 于以南地区倾向率(科左中旗地区除外)。突变后 气候倾向率值变化范围同样较突变前有所增大,但
显著及极显著增温的面积突变后减少 $1.52 \%$ 。

年最低气温突变前 (图 4e) 整个科尔沁沙地呈 升温趋势, 显著升温的面积占 $58.10 \%$, 极显著升温 的面积占 $19.20 \%$ (见图 5c 及表4), 西部升温趋势大 于东部。突变后 (图4f)大部地区仍然呈升温趋势, 
显著升高的面积占 $35.67 \%$, 极显著升高的面积占 48.42\% (见图 5d 及表 4); 在翁牛特旗周围呈降低趋 势,整体表现为自东向西沿新开河到西辽河的以北 地区倾向率大于以南地区倾向率。突变后气候倾 向率值变化范围同样较突变前有所增大, 且显著及 极显著增温的面积突变后较突变前增加了 $6.79 \%$ 。

\section{4 结论与讨论}

\section{1 结论}

(1)年(季)各气温要素突变年份均表现为最低 气温早于平均气温, 早于最高气温; 除最低气温的 春、冬季突变年份一致外(1981年),其它气温要素 四季突变顺序依次为冬季、春季、秋季、夏季,所有 要素中年、春季、冬季最低气温突变的时间最早 (1981 年), 夏季最高气温突变的时间最晚 (1999 年)。

(2)年最低气温(冬季各气温要素)突变后比突 变前、春(秋)季最低气温突变前比突变后、冬季气 温比夏季气温变化更剧烈;年、春季、秋季各气温要 素变化的剧烈程度以最低气温、平均气温、最高气 温的顺序依次减弱,冬季各气温要素与之相反。

(3) 突变前春季最低气温气候倾向率为 $0.50^{\circ} \mathrm{C} /$ $10 \mathrm{a}$, 突变后秋季最高气温气候倾向率为 $0.75^{\circ} \mathrm{C} /$ $10 \mathrm{a}$, 二者对升温的贡献最大, 突变前周期波动较突 变后明显。

（4)春季、秋季、冬季最低气温多年均值突变前 后增量最大, 分别为 $1.74^{\circ} \mathrm{C} 、 1.35^{\circ} \mathrm{C} 、 1.02^{\circ} \mathrm{C}$, 最高气 温最小, 分别为 $0.92^{\circ} \mathrm{C} 、 0.85^{\circ} \mathrm{C} 、 0.96^{\circ} \mathrm{C}$, 夏季最高气 温增量最大, 为 $1.16^{\circ} \mathrm{C}$, 最低气温增量最小, 为 $1.02^{\circ} \mathrm{C}$ 。突变前后多年均值增量最大为冬季最低气 温 $\left(1.86^{\circ} \mathrm{C}\right)$, 最小为年最高气温 $\left(0.83^{\circ} \mathrm{C}\right)$; 气候倾向 率增量最大为秋季最高气温 $\left(0.72^{\circ} \mathrm{C} / 10 \mathrm{a}\right)$, 最小为夏 季最高气温 $\left(-0.02^{\circ} \mathrm{C} / 10 \mathrm{a}\right)$; 四季中,各气温要素突 变前后多年均值增量大的季节,增温速率增量反而 小,二者呈相反的变化趋势。

(5)空间上年气温各要素突变后气候倾向率值 变化范围均较突变前增大, 年最低气温突变后显著 升温面积比突变前增大 $6.79 \%$ 。突变前,除最低气 温的空间分布规律和科左中旗地区最高气温外,表 现为沿老哈河到新开河以北地区升温速率大于以 南地区升温速率; 突变后, 除科左中旗地区平均气
温外,表现为自东向西沿新开河到西辽河的以北地 区升温速率大于以南地区升温速率。

\section{2 讨论}

综上所述,科尔沁沙地各类气温发生了全面突 变, 突变后升温速率更显著。与全球气温突变产生 的诸多影响如干旱程度增加, 生物多样性减少, 物 候期提前、植被生产力减少, 冰雪融化、海平面上 升,极端天气发生频率增加等类似 ${ }^{[37]}$, 气温突变对研 究区气候、植被、水资源、农牧业等方面产生很多影 响, 极端气候事件发生频率和强度不断增大。研究 区最低气温升高趋势十分显著,1951-2012年的三 次历史最高记录都出现在气温突变后,近 10 年局部 沙化区域仍有向西北扩张趋势 ${ }^{[38]}$, 与本次突变前后 西北部升温速率呈持续加快趋势相吻合, 表明沙漠 化与气温升高有密切的联系。除此之外, 研究区干 旱、洪涝、霜冻等极端气候事件发生概率亦增多 ${ }^{[39,40]}$; 蒸发量增大,加剧浅层潜水的咸化;植物多样性减 少 ${ }^{[41]}$ 。另外, 也有一些有利影响, 如中晚熟农作物品 种产量提高, 冬季气候变暖有利于牲畜安全越冬和 接羔保育等 ${ }^{[42]}$ 。

在宏观尺度上,科尔沁沙地气温变化符合全球 变化规律, 其变化驱动力是自然因素和人类活动共 同作用的结果 ${ }^{[43]}$ 。根据前人研究结果, 气温突变的 自然因素为北极涛动 $(\mathrm{AO})$ 的影响主要集中在中高 纬地区 (含科尔沁沙地), 北大西洋涛动 (NAO) 在 20 世纪 70 年代末强度增强,本次研究区最低气温突变 时间与之相呼应, 另与东亚地区冬季气旋/反气旋活 动及寒潮的显著变化有一定联系; 太阳活动通过平 流层温度场和风场, 改变大气环流空间结构,亦进 而影响气候变化。火山活动、臭氧、气溶胶等也可 能是影响因素.另外, ENSO 其中之一的极地/欧亚型 涛动, the Polar/ Eurasian Pattern $(\mathrm{P} / \mathrm{E})$ 是冬季最主要 的大气低频变化, 它的其中一个中心位于中国东 北,且只出现在冬季, 对东北地区气温变化影响显 著 ${ }^{[44]}$, 而本次研究区位于东北地区西南方向,在最低 气温为升温的主要驱动力背景下, 冬季最高气温突 变前后、平均气温和最低气温突变前升温速率的不 显著亦可能是受 $\mathrm{P} / \mathrm{E}$ 的影响。多年来,全球及研究 区人口增加、生产活动加强、经济社会不断发展导 致城市化热导效应增强等都可能是造成气温升高 
的重要人类活动因素。

本文对研究区气温突变做了详细分析, 但由于 数据时间长度有限, 对于长期气温变化规律分析及 气温升高原因的剖析存在一定局限性。此外,使用 数据为处理后的区域平均值, 由其来反映整个研究 区气温突变特征, 忽略了区域异质性, 对结果代表 性亦将产生一定影响。本次研究不仅对于深人了 解并揭示中国干早寒冷地区气候变化规律有一定 科学借鉴意义, 而且对于科尔沁沙地生态环境、农 牧业发展、水资源开发利用等生产生活有一定实践 指导意义,亦为全球气候研究最终目标一一定量阐 明地球系统过去变化规律及其过程,增进对未来气 候、环境变化预测和制定可持续发展战略 ${ }^{[45}$ 提供一 定借鉴。

\section{参考文献(References) :}

[1] 沈永平,王国亚. IPCC 第一工作组第五次评估报告对全球气 候变化认知的最新科学要点[J]. 冰川冻土,2013,35(5): 10681076. [Shen Y P, Wang Y G. Key fining and assessment result of IPCC WGI fifth assessment report[J]. Journal of Glaciology and Geocryology,2013,35(5):1068-1076.]

[2] Stocker T F, Qin D, Plattner G K, et al. Climate Change 2013: The Physical Science Basis. Contribution of Working Group I to the Fifth Assessment Report of the Intergovernmental Panel on Climate Change[R]. Cambridge: Cambridge University Press, 2013.

[3] 符淙斌,马柱国. 全球变化与区域干旱化[J]. 大气科学, 2008, 32 (4) : 752-760. [Fu C B, Ma Z G. Global change and regiona aridification[J]. Chinese Journal of Atmospheric Sciences (in Chinese), 2008,32(4):752-760.]

[4] Dai A G. Increasing drought under global warming in observations and models[J]. Nature Climate Change, 2013,3(1):52-58.

[5] Gobiet A, Kotlarski S, Beniston M, et al. 21st century climate change in the European Alps-A review[J]. Science of the Total Environment, 2014,493:1138-1151.

[6] Aghakouchak A, Cheng L Y, Mazdiyasni O, et al. Global warming and changes in risk of concurrent climate extremes: Insights from the 2014 California drought[J]. Geophysical Research Letters, 2014,41(24):8847-8852.

[7] 吴国雄,林海,邹晓蕾, 等. 全球气候变化研究与科学数据 [J]. 地球科学进展, 2014,29(1) : 15-22. [Wu G X, Lin H,Zou X L, et al. Research on global climate change and scientific date[J]. Advances in Earth Science, 2014,29(1):15-22.]
[8] 马柱国,符淙斌. 20 世纪下半叶全球干旱化的事实及其与大尺 度背景的联系 [J]. 中国科学 D 辑: 地球科学, 2007,37(2): 222233. [Ma Z G, Fu C B. The fact of global drought contact with its long-time-scale background in the second half of the 20th century [J]. Science China (Series D: Earth Science) , 2007, 37 (2) : 222233.]

[9] Jones P D, Moberg A. Hemispheric and large-scale surface air temperature variations: An extensive revision and an up-date to 2001[J]. Journal of Climate, 2003,16(2):206-223.

[10] 王劲松,陈发虎,靳立亚,等. 亚洲中部干旱区在 20 世纪两次暖 期的表现[J]. 冰川冻土, 2008, 30(2):224-233. [Wang J S, Chen $\mathrm{F} \mathrm{H}$, Jin L Y, et al. The response to two global warming periods in the 20th century over the arid central Asia[J]. Journal of Glaciology and Geocryology,2008,30(2):224-233.]

[11] Ji F, Wu Z H, Huang J P, et al. Evolution of land surface air temperature trend[J]. Nature Climate Change, 2014, 4 (6) : 462466.

[12] Li B, Chen Y, Shi X. Why does the temperature rise faster in the arid region of northwest China[J]. Journal of Geophysical. Research Atmospheres, 2012,117(D16):81-81.

[13] Wang H, Chen Y, Chen Z. Spatial distribution and temporal trends of mean precipitation and extremes in the arid region, northwest of China, during 1960-2010[J]. Hydrological Processes, 2012,27(12):1807-1818.

[14] 花婷,王训明,郎丽丽,等. 甘肃省气温与降水变化趋势及其对 主要流域径流量的影响[J]. 中国沙漠, 2015,31(3): 788-792. [Hua T, Wang X M, Lang L L, et al. Responses of desertification to climate change in arid and semiarid regions of China over the past millennium[J]. Journal of Desert Research, 2015,31(3) : 788792.]

[15] 张宏芳,潘留杰,卢珊, 等. 1901-2012年陕西降水、气温变化特 征[J]. 中国沙漠, 2015,35 (6) : 1-9. [Zhang H F, Pan L J, Lu S, et al. Variation characteristics of precipitation and air temperature from 1901 to 2012 in Shaanxi, China[J]. Journal of Desert Research, 2015,35(6): 1-9.]

[16] 李育,朱耿睿. 年际-年代际尺度中国气候区类型变化与影响 因素研究[J]. 资源科学, 2015,37(3):605-618. [Li Y,Zhu G R. Interannual-interdecadal changes in climate zones in China and controlling factors[J]. Resources Science, 2015,37(3) :605-618.]

[17] 周釒金. 中国气温的年际-年代变化特征及其模拟实验研究[D]. 南京：南京信息工程大学, 2013. [Zhou X. Analysis on Interannual and Interdecadal Variability of Temperature Over China and Its Simulation[D]. Nanjing: Nanjing Information and Engineering Univeristy ,2013.]

[18] 韩翠华,郝志新,郑景云. 1951-2010年中国气温变化分区及其 区域特征[J]. 地理科学进展, 2013,32(6):887-896. [Han C H, Hao Z X, Zheng J Y. Regionalization of temperature changes in 
China and characteristics of temperature in different regions during 1951-2010[J]. Progress In Geography, 2013,32(6) : 887896.]

[19] 贺伟,布任仓,熊在平, 等. 1961-2005 年东北地区气温和降水 变化趋势[J]. 生态学报,2013,33(2):519-531. [He W, Bu R C, Xiong Z P, et al. Characteristics of temperature and precipitation in Northeastern China from 1961 to 2005[J]. Acta Ecologica Sinica, 2013,33(2):519-531.]

[20] 王菱,谢贤群,苏文,等. 中国北方地区 50 年来最高和最低气温 变化及其影响[J]. 自然资源学报,2004,19(3):337-343. [Wang $\mathrm{L}, \mathrm{Xie} \mathrm{X} \mathrm{Q}, \mathrm{Su}$ W, et al. Changes of maximum and minimum temperature and their impacts in northern China over the second half of the 20th century[J]. Journal of Natural Resources , 2004, 19 (3) :337-343.]

[21] 李春籊,董治宝, 常佩静, 等. 阿拉善高原近 $45 \mathrm{a}$ 来气温变化特 征分析[J]. 中国沙漠, 2011,31(3):788-792. [Li C X, Dong Z B, Chang P J, et al. Analysis on mean air temperature changes in Alxa Plateau in last 45 years[J]. Journal of Desert Research,2011, 31(3) :788-792.]

[22] 陈隆勋, 周秀骥, 李维亮. 中国近 80 年来气候变化特征及其形 成机制[J].气象学报, 2004,62(5):634-646. [Chen L X,Zhou X

J, Li W L. Characteristics of the climate change and its formation mechanism in China in last 80 years[J]. Acta Meteorologica Sinica, 2004,62(5) :634-646.]

[23] 陈少勇,王劲松,石圆圆,等. 中国东部季风区 1961年 2006年 年平均气温变化特征 [J]. 资源科学, 2009, 31 (3) : 462-471. [Chen S Y, Wang J S, Shi Y Y, et al. The change of annual mean temperature in monsoon area of east China[J]. Resources Science, $2009,31(3): 462-471$.

[24] 李小燕,任志远, 张羽. 陕南气温变化的时空分布 $[J]$. 资源科 学, 2012,34(5) : 927-932. [Li X Y, Ren Z Y, Zhang C. Spatial and temporal distribution of temperature changes in southern Shaanxi[J]. Resources Science, 2012,34(5 ):927-932.]

[25] 丁明军,李兰晖,张镱锂, 等. 1971-2012 年青藏高原及周边地 区气温变化特征及其海拔敏感性分析[J]. 资源科学, 2014,36 (7) : 1509- 1518. [Ding M J, Li L H, Zhang Y L, et al. Temperature change and its elevation dependency on the Tibetan plateau and its vicinity from 1971 to 2012[J]. Resources Science, 2014,36(7):1509-1518.]

[26] 向辽元,陈星. 近 55 年中国大陆气温突变的区域特征和季节特 征 $[J]$. 气象, 2006,32(6):44-47. [Xiang L Y, Chen X. Regional and seasonal features of abrupt temperature change in China in recent 55 Years[J]. Meteorological Monthly, 2006,32 (6):44-47.]

[27] 丹丹,春喜,刘美萍, 等. 1951-2010年内蒙古霍林河流域气候 变化特征[J]. 冰川冻土, 2013,35(4) : 874-882. [Dan D, Chun X, Liu M P, et al. Characteristics of climate change in Huolin River basin, Inner Mongolia, I95I-2010[J]. Journal of Quaternary
Sciences , 2013,35(4) :874-882.]

[28] 王红梅,骆永明,蒋德明. 科尔沁沙地乌兰敖都地区最高和最 低气温的变化趋势[J]. 中国农业气象, 2007,28(2):124-127. [Wang H M, Luo Y M, Jiang D M. Variation trends of maximal and minimal air temperature at Wulanaodu Region, Horqin Steppe [J]. Chinese Journal of Agrometeorology, 2007,28(2) : 124-127.]

[29] 王红梅,骆永明,蒋德明. 科尔沁沙地翁牛特旗气温的非对称 变化分析 [J]. 干旱区研究, 2007,24(2):261-267. [Wang H M, Luo Y M, Jiang D M. Unsymmetrical variation of the maximum and minimum air temperatures in Wengniute Banner, Horqin Sand Land[J]. Arid Zone Research,2007,24(2) :261-267.]

[30] 杨振常,李玉霖,崔夺,等. 半干早典型沙区 1951-2005年主要 气象要素及潜在蒸散量的变化趋势研究[J]. 中国沙漠, 2012, 32(5) : 1384-1392. [Yang Z C, Li Y L, Cui D, et al. Changes of main climatic parameters and potential evapotranspiration in typical semi- arid sandy lands of northern China during 19512005[J]. Journal of Desert Research ,2012,32(5 ) :1384-1392.]

[31] 渠翠平,关德新,王安志,等. 近 56 年来科尔沁沙地气候变化特 征[J]. 生态学杂志, 2009,28(11) :2326-2332. [Qv C P, Guan D $\mathrm{X}$, Wang A Z, et al. Characteristics of climate change in Horqin Sandy Land in past 56 years[J]. Chinese Journal of Ecology, 2009, 28(11):2326-2332.]

[32] 蒋德明,刘志民,寇振武,等. 科尔沁沙地生态环境及其可持续 管理-科尔沁沙地生态考察报告[J]. 生态学杂志, 2004,23 (5)： 179-185. [ Jiang D M, Liu Z M, Kou Z W, et al. Ecological environment and its sustainable management of Horqin steppe-A report on the survey of Horqin sandy land[J]. Chinese Journal of Ecology,2004,23(5):179-185.]

[33] 董满宇,江源,任斐鹏,等. 近 $50 \mathrm{a}$ 来北方农牧交错带气温变化 趋势及突变分析[J]. 中国沙漠,2010,30(4):926-932. [Dong M Y, Jiang Y, Ren F P, et al. Variation trend and catastrophe change of air temperature in the farming pastoral ecotone of northern China during recent 50 years[J]. Journal of Desert Research ,2010, 30(4):926-932.]

[34] 马龙, 刘廷玺. 科尔沁沙地典型区域地表环境变化与气候变化 的响应关系 [J]. 冰川冻土, 2009,31 (6) : 1063-1073. [Ma L, Liu T X, Ji H L, et al. Establishment of ring width chronology and rainfall reconstruction of Ulmus pumila L. in Horqin Sandy Land Since 1826[J]. Quaternary Sciences , 2009,31 (6) : 1063-1073.]

[35] 20 个气象站点的数据来源于内蒙古自治区气象局, 5 个气象站 点的数据来源于吉林省气象局, 2 个气象站点的数据来源于辽 宁省气象局。

[36] 符淙斌.气候突变现象的研究[J]. 大气科学, 1994,16(4):373384. [Fu C B. Studies on the observed abrupt climatic change[J]. Chinese Journal of Atmospheric Sciences (in Chinese) , 1994, 16 (4) :373-384.]

[37] 张文. 近百年来气候突变与极端事件的检测与归因的初步研 
究[D]. 扬州: 扬州大学, 2007. [Zhang W. Climate Mutation and Extreme Events of the Preliminary Research on the Detection and Attribution over the Past Century[D]. Yangzhou: Yangzhou University, 2007.]

[38] 段翰晨, 王涛,薛涃,等. 基于 RS 与 GIS 的科尔沁沙地沙漠化时 空演变[J]. 中国沙漠, 2013,33(11):470-477. [Duan H C, Wang

T, Xue X, et al. Spatial-temporal evolution of desertification in the Horqin sandy land based on RS and GIS[J]. Journal of Desert Research,2013,33(11):470-477.]

[39] 张桂英,姜秀萍,周光会, 等.气候变暖背景下科尔沁沙地 50 年 霜冻变化分析[J]. 中国农学通报, 2013,29(26): 161-164 [Zhang G Y, Jiang X P, Zhou G H, et al. Climate change under the background of dim Horqin sandy land 50 years frost change analysis[J]. Chinese Agricultural Science Bulletin, 2013, 29(26) : 161-164.]

[40] 白美兰,郝润全,邸瑞琦, 等. 内蒙古东部近 54年气候变化对生 态环境演变的影响[J]. 气象, 2006,32(6):31-36. [Bai M L, Hao R Q, Di R Q, et al. Effects of climatic changes in eastern Inner Mongolia on eco- environmental evolution in last 54 years[J]. Meteorological Monthly,2006,32(6):31-36.]

[41] 吴循, 周青.气候变暖对陆地生态系统的影响[J]. 中国生态农 业学报,2008,16(6):223-228. [Wu X,Zhou Q. Effect of climate change and global warming on terrestrial ecosystems[J]. Chinese Journal of Eco-Agriculture, 2008, 16 (6) : 223-228.]

[42] 尤莉, 王国勤, 阎军, 等. 内蒙古科尔沁沙地气候变暖及对农牧 业的影响[A]. 中国气象学会农业气象与生态学委员会, 广西壮 族自治区气象学会. 粮食安全与现代农业气象业务发展-2008
年全国农业气象学术年会论文集[C]. 南宁: 广西壮族自治区气 象学会, 2008. [You L, Wang G Q, Yan J, et al. Inner Mongolia Horqin Sandy Climate Warming and Impact on Agriculture and Animal Husbandry[A]. Agricultural Meteorology and ecology Committee of China Meteorological Society, Guangxi Zhuang Autonomous Region Meteorological Society. Food Security and Modern Agricultural Meteorology Business Development- 2008 National Agricultural Meteorology Annual Conference Proceedings [C]. Nanning: Guangxi Zhuang Autonomous Region Meteorological Society , 2008.

[43] 杨周,林振山. 北半球过去 2000 年气温变化的多尺度分析 [J]. 地理科学, 2010,30(2) :296-299. [Yang Z, Lin Z S. Multi-scale analysis of Northern Hemisphere temperature changes over past two millennia[J]. Scientia Geographica Sinica , 2010, 30(2) : 296299.]

[44] 张晶晶,陈爽,赵昕奕. 近 50年中国气温变化的区域差异及其 与全球气候变化的联系 [J]. 干旱区资源与环境, 2006,20(4): 1-6. [Zhang J J, Chen S, Zhao X Y. Spatial divergency of temperature change during 1951- 2000 in China and its correlation with global climate change[J]. Journal of Arid Land Resources and Environment, 2006,20(4):1-6.]

[45] 葛全胜,郑景云,郝志新, 等. 过去 2000 年中国气候变化研究的 新进展[J]. 地理学报, 2014,69(9):1248-1258. [Ge Q S,Zheng J Y, Hao Z X, et al. State- of-the-arts in the study of climate changes over China for the past 2000 years[J]. Acta Geographica Sinica , 2014,69(9): 1248-1258.] 


\title{
Comparative analysis of temperature before and after abrupt changes in Horqin Sandy Land from 1951 to 2012
}

\author{
WANG Jingru, MA Long, LIU Tingxi, HUANG Xing, LIU Danhui, LI Hongyu \\ (College of Water Conservancy and Civil Engineering College, Inner Mongolia Agricultural University, Hohhot 010018, China)
}

\begin{abstract}
Based on temperature data from 1951 to 2012 we analyzed abrupt change features of temperature and temporal and spatial variation before and after abrupt temperature change. We found that year (season) minimum temperature changed (1981-1987), followed by year (season) mean temperature (1981-1994), and then year (season) maximum temperature (1985-1999). Winter temperatures have changed more abruptly than summer temperatures; minimum temperature was more abrupt than mean temperature, mean temperature was more abrupt than maximum temperature in spring (autumn and annual) ; winter shows the opposite pattern. Before the abrupt change in minimum temperature $\left(0.50^{\circ} \mathrm{C} / 10 \mathrm{a}\right)$ in spring, after the abrupt change of the maximum temperature in autumn $\left(0.75^{\circ} \mathrm{C} / 10 \mathrm{a}\right)$, are the largest contributor to temperature rise. Across all of the elements of temperature before and after abrupt change, the largest incremental mean value for many years is the winter minimum temperature $\left(1.86^{\circ} \mathrm{C}\right)$ and the smallest is annual maximum temperature $\left(0.83^{\circ} \mathrm{C}\right)$. The largest incremental climate tendency rate is the autumn maximum temperature $\left(0.72^{\circ} \mathrm{C} / 10 \mathrm{a}\right)$ and the smallest is the summer maximum temperature ( $\left.0.02^{\circ} \mathrm{C} / 10 \mathrm{a}\right)$. Seasonal order of incremental mean temperature value for many years before and after abrupt change is opposite to their incremental climate tendency rate. The value range of all annual temperature elements' climate tendency rates after abrupt change are wider than before abrupt change; the area of annual minimum temperature increasing significant abrupt change increased by $6.79 \%$ compared with their before abrupt change. For the Xinkai and Xiliao Rivers the warming trend is higher than for other regions after abrupt change, except for the mean temperature for the Horqin Left Wing Middle Banner region. This study not only has a practical guide on ecological environment, farming and stockraising development, water resources development and utilization and and so on production and fliving but also has a certain scientific reference on global climatic change law.
\end{abstract}

Key words : Horqin Sandy Land; temperature; abrupt change; temporal and spatial variability; comparative analysis 